\title{
Effect and Consequence e-Customer Satisfaction for e-Commerce Users
}

\author{
Rolan Patrada and Erna Andajani \\ ${ }^{1}$ Departemen of Psychology Universitas Surabaya, Surabaya \\ ${ }^{2}$ Departemen of Management Universitas Surabaya, Surabaya \\ e-mail:patrada.rolan@gmail.com
}

\begin{abstract}
The 4.0 industrial revolution has changed people's behavior to use everything through technology. This happens also in terms of shopping that can be done by many people through e-commerce. This study aims to examine the effect of online convenience, website design, security, information quality, and e-service quality on e-word of mouth, behavioral intentions, and e-loyalty through e-customer satisfaction respondents who use e-commerce to shop at Indonesia, especially Surabaya. The data used in this study are primary data obtained through distributing questionnaires to 205 respondents who are male and female e-commerce users, who are at least $\mathbf{1 5}$ years old, and have conducted transactions in ecommerce at least 5 times in the past year. The sampling technique in this study is non-probability sampling. This research uses a quantitative approach using statistical testing. The test was carried out using the Structural Equation Modeling (SEM) method with the SMART-PLS 3.0 program. The results of this study indicate that only online convenience, security, and information quality have an influence on other dependent variables through e-customer satisfaction, while website design and e-service quality have no effect.
\end{abstract}

Keywords-Online Convenience, Website Design, Security, Information Quality, e-Service Quality, e-Word of Mouth, Behavioral Intentions, e-Loyalty, e-Customer Satisfaction, eCommerce.

\section{INTRODUCTION}

$\mathrm{T}$ $\mathrm{HE}$ industrial revolution 4.0 is very interesting topic and often raised in various forums. This is because the presence of the 4.0 industrial revolution affected various fields of human life, especially in the economic field. Changes in the industrial revolution did not occur in decades, but in a matter of months. Building the right ecosystem is also important to face this industrial revolution. For example a company that is already able to change people's habits and behavior is Go-Jek company.

The rapid development that occurs in the world of technology has an impact on changes to producers and consumers. The current acceleration in the use of information technology, especially on social media provides changes to consumer behavior in terms of communication, information sharing, recommend products and interactions are connected in social media [1]. The consumer's need to get information fast, specific and easy to access through a smartphone provides a change in ways of thinking, lifestyle, existence, self-esteem, social culture, and to eliminate moral ethics in social life. Lifestyle leads to practical and instant culture makes online shop and food delivery services using applications, motorcycle taxis and online taxis grow rapidly [1]. A survey by APJII (Indonesian Internet Service
Providers Association) showed the number of internet users in Indonesia in 2017 reached 143.26 million. This shows that more than 50 percent of Indonesia's total population already use the internet in their daily lives. Research conducted by Google and GfK (Gesellschaft fur Konsumforschung) shows the city of Surabaya is ranked first in the use of e-commerce and marketplaces in Indonesia and shifts e-commerce trends in Jakarta.

According to Dailysocial.id survey data (2018) shows that e-commerce which is the most visited by Indonesian people is Tokopedia with 111.46 million people visiting the ecommerce every month. Another survey conducted by Dailysocial.id (2018) showed that the categories of goods most frequently purchased by the Indonesian people were electronic goods and gadgets and ranked second was the fashion goods category. These categories of goods are spread across 6 e-commerce sites in Indonesia, namely Blibli.com, Bukalapak, JDiD, Lazada, Shopee, and Tokopedia.

Duarte et.al (2018) explain that the customer's decision to make a purchase is significantly influenced by the speed and ease of contacting a store or retail [2]. Beauchamp and Ponder Duarte et.al (2018) explain the transition of customers to the world of the internet or online shop because customers want to reduce the effort given when making a purchase decision [2]. Customers who make online purchases can perform various other activities at the same time, so that it will make the time and effort spent more effectively when performing various tasks at one time. Research conducted by Duarte et.al (2018), wants to explain the influence of the convenience of online shop shopping on online customer satisfaction which will also affect electronic Word of Mouth (e-WOM) and behavioral intentions. The convenience described in this study is divided into several aspects, namely access convenience, search, evaluation, attentiveness, transaction, possession, and post-possession. The role of customer satisfaction in this study is as a mediation between the convenience of online shopping with behavioral intention and e-WOM. The results of Duarte et.al (2018) showed that the influence of online shopping convenience on behavioral intention and e-WOM was mediated by customer satisfaction [2]. Another study was conducted by ludin (2014) to find out what factors can influence customer satisfaction and e-loyalty to the environment of early adult individuals who shop online in Malaysia. The factors examined in this study are website design, security, quality of electronic services, and quality of information. The results of a study conducted by Ludin and 
The $1^{\text {st }}$ International Conference on Business and Engineering Management (IConBEM 2020)

February $1^{\text {st }} 2020$, Institut Teknologi Sepuluh Nopember, Surabaya, Indonesia

Cheng (2014) show that significant effects only occur between e-service quality and customer satisfaction, and information quality with customer satisfaction. The relationship between customer satisfaction and e-loyalty also significantly positive. This shows that the quality of electronic services and the quality of good information will increase customer satisfaction who shop at online stores. Furthermore, satisfied customers when shopping tend to make repeat purchases and be loyal to the store.

Based on previous studies, it can be concluded that to achieve customer satisfaction from online store customers requires good service quality, good quality information, adequate online convenience for customers when using applications. When an online store can meet these needs, then customer satisfaction will be achieved and will also affect the level of customer loyalty to e-commerce (eloyalty), the intensity to buy back on the e-commerce in question will increase (behavioral intentions) and customers will recommend e-commerce to other customers to attract new customers to come and buy goods or services provided (e-WOM). This study combines the framework of research conducted by Duarte et.al (2018) and Ludin \& Cheng (2014) by adding e-loyalty variables as dependent variables and website design, security, e-service quality and information quality variables as independent variables. The e-commerce used in this study are Tokopedia, Shopee, Bukalapak, Lazada, and Blibli.com because the five e-commerce sites are the most visited and used by people in Indonesia.

Satisfaction is a comparison between customer expectations before making a purchase and the results received when a customer has made a purchase [3]. Kotler and Keller (2016) define satisfaction as feelings of pleasure or disappointment from individuals which is the result of a comparison between services or goods received with expected. E-satisfaction is the customer's assessment of the experience gained from online retail compared to the experience with experience gained from traditional retail[4]. Anderson and Srinivasan (2003 describe e-satisfaction as the pleasure felt by individuals in connection with the purchase experience made through online stores.

Research conducted by Duarte et.al (2018) shows that there is an influence of online convenience on e-customer satisfaction [2].The comfort felt by the customer when using an e-commerce application or website will increase the satisfaction felt by the customer when making a purchase transaction. Customers who easily feel comfortable in making transactions and get benefits in an e-commerce, the customer will be easier to feel satisfaction. Ludin and Cheng (2014) found that customer satisfaction is influenced by two things, namely e-service quality and information quality. Good quality electronic services from e-commerce will make customers who make transactions feel satisfied with the service received . The quality of information provided in an e-commerce website or application is also a factor that will affect the level of customer satisfaction. Ludin and Cheng explained that e-commerce websites or applications should be informative and able to provide valuable information to customers so as to shorten the time needed forcustomersto find information. Research conducted by Meidita (2018) and Wijiutami and Octavia (2017) explain that service quality is a factor influencing the achievement of customer satisfaction. Both studies show that the level of quality of services provided by e-commerce will affect the level of satisfaction felt by customers when making a purchase transaction in e-commerce.

The concept of convenience was first used to indicate the size of the time and effort expended to buy a product [2]. Duarte et.al (2018) define convenience as the time and effort costs incurred by consumers related to shopping carried out in a retail environment. Convenience is saving customers' time and effort when making a product purchase transaction in Farquhar [2].

Duarte et.al (2018) in their research divide the online convenience dimension into seven, namely; (1)Access convenience: the ease and speed of customers to get to retail places. In the condition of online retailing, the intended access is when customers can easily and quickly use the website or application used by e-commerce in order to obtain information or products from the goods or services being sold; (2)Search convenience: the ease and speed of customers to find and choose the products that customers want to buy. The more effective the business that an ecommerce company gives to facilitate the search for products from customers, the faster and easier the customer will be to find the desired item; (3)Evaluation convenience: availability of details and ease of product description to be understood by using presentation features in e-commerce which include text, graphics and video. The instrument provided allows customers to get clear product images and make modifications (changing colors, types, etc.) according to customer requirements; (4)Attentiveness convenience: the extent to which online retail is able to provide personal services and attention to customers as a form of cost reduction in the form of customer time and effort. Modern online retailers use a variety of personalization features to differentiate their products and services based on service modification and personalization, enhancing the experience and comfort that can be felt by the customer as a whole; (5)Transaction convenience: ease and speed that can make customers change or influence transactions. One of the advantages of customers who make purchases online is that they don't need to queue when making a purchase transaction until payment. Online shoppers are on a "virtual path" that allows each buyer to complete a transaction simultaneously; (6)Possession convenience: the speed and ease of customers in getting the desired product that can be influenced by production planning, inventory policy, expeditions and delivery time. Customers who make purchases online must wait for product orders through the process of handling, shipping and delivery time before they can have the desired item; (7)Post-possession convenience: time and effort spent by the customer when making contact again to the company after the product purchase process is complete. Factors that influence post-possession convenience are related to customer needs to make repairs, maintenance and exchange of products. 
The $1^{\text {st }}$ International Conference on Business and Engineering Management (IConBEM 2020)

February $1^{\text {st }} 2020$, Institut Teknologi Sepuluh Nopember, Surabaya, Indonesia

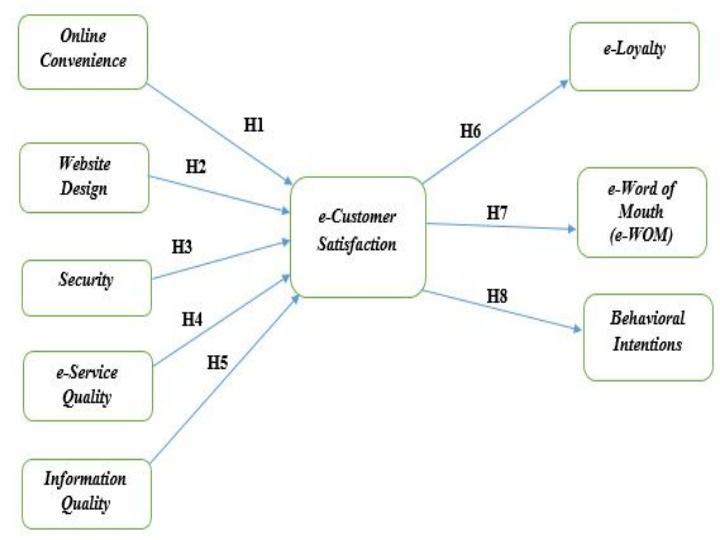

Figure 1. Theoretical Framework.

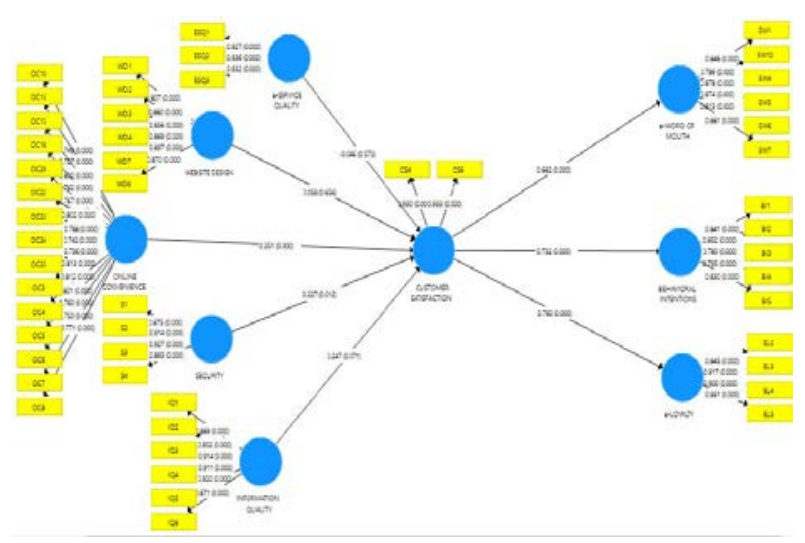

Figure 2. Outer Loadings.

\section{A. The influence of online convenience on e-customer satisfaction}

Online convenience is a savings that can be done by customers in terms of time and effort when making purchases of goods or services through online retail. Online convenience has seven dimensions, namely access convenience, search convenience, evaluation convenience, attentiveness convenience, transaction convenience, possession convenience, and post-possession convenience. Based on research conducted by Duarte et.al (2018) explains the influence of online convenience on online customer satisfaction. The research shows that customers who can shop and use applications or websites comfortably will make these customers satisfied with the e-commerce or online retail [2]. Duarte et.al (2018) found that e-commerce or online retail customers no longer focus too much on the speed of delivery of goods, but rather lead to experiences that make these customers comfortable and can save more time and effort spent. Some aspects that exist in online convenience lead to the ease and speed of using e-commerce both in the transaction process, access, service after purchasing products, searching for goods, and others [2].

The ease and speed of using an e-commerce application or website supports changes in behavior from buyers which increasingly leads to online or internet-based stores. When customers get products quickly and easily, then the customer will comfortably make a purchase transaction in an ecommerce [2]. The convenience that can be provided by e commerce to customers can start from the process of
Table 1.

Composite Reliability

\begin{tabular}{lc}
\hline \hline \multicolumn{1}{c}{ Variable } & Composite Reliability \\
\hline Online Convenience & .957 \\
Website Design & .945 \\
Security & .946 \\
Information Quality & .962 \\
e-Service Quality & .952 \\
e-Word of Mouth & .937 \\
Behavioral Intentions & .911 \\
e-Loyalty & .933 \\
e-Customer Satisfaction & .929 \\
\hline \hline
\end{tabular}

Table 2.

Average Variance Extracted

\begin{tabular}{ll}
\hline \hline \multicolumn{1}{c}{ Variable } & AVE \\
\hline Online Convenience & .597 \\
Website Design & .740 \\
Security & .815 \\
Information Quality & .807 \\
e-Service Quality & .869 \\
e-Word of Mouth & .713 \\
Behavioral Intentions & .673 \\
e-Loyalty & .776 \\
e-Customer Satisfaction & .867 \\
\hline \hline
\end{tabular}

customers searching for products to services after a purchase to the customer if the product received is not suitable or damaged. The more customers can feel comfortable when making a purchase transaction on an e-commerce, the customer will also be easier to feel satisfied with the services provided from the e-commerce. Based on the description above, the hypothesis is proposed as follows:

H1: there is an influence of online convenience on ecustomer satisfaction, on figure 1.

\section{B. Effect of website design on e-customer satisfaction}

Ranganathan and Grandon define website design as a way to manage content in a site or website [5]. Website design is the ability of website owners (e-commerce) to provide a comfortable environment for customers to access the site [6]. Website design is the ability of e-commerce to organize content on the site so that it can provide a comfortable environment for customers to access the site.

Research conducted by Ludin and Cheng (2014) for customers who use e-commerce in Malaysia shows that there is no influence from website design on e-customer satisfaction felt by these customers when making a purchase transaction [6]. This is contrary to the results of a study put forward by Guo et al (2012) conducted to e-commerce customers in China that showed a significant positive influence on website design on customer satisfaction [7]. Research conducted by Lee and Lin (Guo et al, 2012) also revealed a positive influence between website design and customer satisfaction.

Ludin and Cheng (2014) explain that there is no influence of website design against customer satisfaction due to the minimal frequency of purchases made by research respondents. As many as $46.2 \%$ of respondents in the study only made transactions about 1 to 3 times a month. The frequency triggers the lack of involvement in the ecommerce environment so that the customer does not have much experience with other e-commerce sites in the past. This results in customers not having enough experience to compare one e-commerce with other e-commerce. 
The $1^{\text {st }}$ International Conference on Business and Engineering Management (IConBEM 2020)

February $1^{\text {st }} 2020$, Institut Teknologi Sepuluh Nopember, Surabaya, Indonesia

Table 3.

R-squares

\begin{tabular}{ll}
\hline \hline \multicolumn{1}{c}{ Variable } & $\mathrm{R}^{2}$ \\
\hline e-Word of Mouth & .438 \\
Behavioral Intentions & .536 \\
e-Loyalty & .578 \\
e-Customer Satisfaction & .574 \\
\hline \hline
\end{tabular}

Table 4.

Hypothesis

\begin{tabular}{llc}
\hline \hline & \multicolumn{1}{c}{ Hypothesis } & P-values \\
\hline H1 & Online convenience affects e-customer satisfaction & $0,000^{*}$ \\
H2 & Website design affects e-customer satisfaction & $0,689^{*}$ \\
H3 & Security affects e-customer satisfaction & $0,013^{*}$ \\
H4 & e-Service quality affects e-customer satisfaction & $0,577^{*}$ \\
H5 & Information quality affects e-customer satisfaction & $0,079^{*}$ \\
H6 & e-Customer satisfaction affects e-loyalty & $0,000^{*}$ \\
H7 & e-Customer satisfaction affects e-word of mouth & $0,000^{*}$ \\
H8 & e-Customer satisfaction affects behavioural intentions & $0,000^{*}$ \\
\hline \hline
\end{tabular}

Differences in the results of Ludin and Cheng's (2014) research with Guo et al (2012) show that the environment of e-commerce customers also affects the interest in buying products online. Guo et al (2012) suggested that the online business environment in China encourages managerial strategies to improve performance (website design) so that it can attract buyers' interests and increase customer satisfaction [7]. The information, navigation and visual design of the entire e-commerce site can increase customer satisfaction when shopping through the site. The overall quality of the site design will affect the level of e-customer satisfaction when customers access the site and make a purchase transaction on an e-commerce site [7]. H2: there is an influence of website design on e-customer satisfaction, on figure 1.

\section{The effect of security on e-customer satisfaction}

Security is the ability possessed by a website or site to protect customer's personal information from being opened or disclosed illegally when customers make transactions online [7]. Christy and Matthew (Guo et al, 2012) describe security as the site's ability to protect customer information from being illegally retrieved or used in conducting electronic transactions. Security is defined as protection against security threats in the form of events that have the potential to damage, modify, deny, discard, disclose information, or reduce the efficiency of data or network sources. Security is the ability of e-commerce sites to protect personal information from customers so as not to be opened or revealed irresponsibly in an effort to protect against events that have the potential to be a threat in conducting electronic transactions. Research conducted by Ludin and Cheng (2014) shows that there is no effect of security on e-customer satisfaction felt by customers when conducting transactions through e-commerce. The absence of this influence is because security has more influence on the trust of customers than on customer satisfaction.
Guo et al (2012) show different research results related to the effect of security on customer satisfaction. The study shows the influence of security on customer satisfaction customers who make purchases through e-commerce. Security risks that can be reduced in online purchase transactions will affect the level of satisfaction that the customer will feel. E-commerce sites that are able to provide security to their customers can increase the satisfaction felt by these customers in making a purchase transaction [7]. This is also supported by research conducted by Christian and France France (in Guo et al, 2012) which suggests a positive influence between security and customer satisfaction. H3: there is an influence of security on ecustomer satisfaction, on figure 1.

\section{Effect of e-service quality on e-customer satisfaction}

Lewis and Booms define service quality as a measure that reflects the suitability of the service or services provided to the expectations of the customer [8]. Zeithaml et al describes e-service quality as an efficient and efficient use in shopping, making purchases, and distributing goods or services. Santos explained e-service quality as a comprehensive evaluation and assessment given by customers related to the quality and excellence of e-service provided in the virtual marketplace [7].

E-service quality is a measure that describes customer evaluations and assessments of the suitability of the service or goods received with the expectations held by these customers when making electronic purchase transactions in a virtual marketplace. Based on research conducted by Ludin and Cheng (2014) shows a positive influence between e-service quality on e-customer satisfaction. The biggest challenge in the e-commerce environment is the lack of customers' ability to find out who sells the products or services available on the e-commerce site. High quality electronic services (e-service quality) are expected to be provided by e-commerce parties to overcome the gap between the seller and buyer. With the existence of good eservice quality, it will help customers get in touch with the quality and sellers in the e-commerce, so as to increase customer confidence to conduct online transactions [6]. A good e-service quality must also provide a means of communication between the customer and the seller in ecommerce so that in the end it can affect the level of ecustomer satisfaction from customers when shopping through e-commerce. Research conducted by Guo et al (2012) also explain the positive influence between e-service quality and e-customer satisfaction. E-service quality is a criterion that must be met to build an e-commerce site. Without a good quality management system, businesses cannot provide quality services that are appropriate for customers to increase customer satisfaction [7]. E-commerce that has a good quality of service will benefit to learn the expectations of customers so they can achieve customer satisfaction. Good e-service quality will encourage ecommerce to provide efficient and effective transaction purchasing and product delivery processes to customers [7]. 
The $1^{\text {st }}$ International Conference on Business and Engineering Management (IConBEM 2020)

February $1^{\text {st }} 2020$, Institut Teknologi Sepuluh Nopember, Surabaya, Indonesia

H4: there is an influence of e-service quality with ecustomer satisfaction, on figure 1 .

\section{E. The effect of information quality on e-customer satisfaction}

Information quality is the quality of information that can help users and use that information [9]. Ramirez et al describe information quality as a characteristic of the results offered by information systems that include accuracy, timeliness and completeness of metrics. English defines information quality as the reliability of information in accordance with customer desires through information services that can empower so that it can play a role successfully [10].

Information quality is the reliability and quality and information offered by the information system to meet the user's wishes related to the information so that users can be helped in using information and can empower users of that information. Ludin and Cheng (2014) suggested a positive influence between information quality and e-customer satisfaction. The information provided on the e-commerce site must be precise and valuable for customers in order to reduce the customer's time in finding the products needed. Information on the site becomes important for customers for the search process and evaluation stage [6]. This is because the information provided will help customers make better purchasing decisions which will ultimately increase customer satisfaction [4]. H5: there is an influence of information quality with e-customer satisfaction, on figure 1.

\section{F. Effect of e-customer satisfaction on e-loyalty}

Ltifi and Gharbi (2012) define loyalty as an ongoing relationship built by the customer towards a brand or brand. This represents the expression of emotions that connects customers in a buying or consumption situation. Loyalty is the frequency of repeated purchases or volume relative to the purchase of the same brand. Srinivasan et.al describes eloyalty as a beneficial behavior of customers towards online stores (e-retail) which results in repeated purchases in the same store. Anderson and Srinivasan (2003) describe eloyalty as a positive attitude displayed by customers to electronic or online businesses that result in repeat buying behavior.

Ludin and Cheng (2014) state customer satisfaction as a factor that makes customers become loyal to an e-commerce [6]. The study shows the influence of customer satisfaction on e-loyalty of e-commerce customers. Customers who get satisfaction when shopping at an e-commerce will tend to make repeat purchases and are loyal to the store. In addition, research conducted by Ltifi and Gharbi (2012) shows the influence of e-satisfaction on e-loyalty. The research shows that e-commerce customers who are cognitively and emotionally satisfied will tend to make repeat purchases in the e-commerce.

Sardinha (2015) explains that what affects e-loyalty from customers is e-satisfaction and e-trust. The study found that the trust of customers can affect the level of loyalty of these customers to e-commerce. This is because when a customer already believes in an e-commerce, it will enable the customer to return and be loyal to make a purchase transaction on the e-commerce. In addition, when the company manages to provide positive emotions to customers through goods or services provided and in accordance with customer expectations, then the customer will tend to make repeat purchases and are loyal to the company.

E-Loyalty is a beneficial attitude from customers in the form of repeated buying behavior towards an online store brand (e-commerce) as a form of ongoing relationship between customers and e-commerce and represents the emotional expression of customers. Ludin and Cheng (2014) found a strong influence of customer satisfaction on eloyalty from customers who use e-commerce in Malaysia. The higher satisfaction felt by the customer will encourage increased customer loyalty [6]. This is because when customers are satisfied feel confident that they will get satisfying experience and services at the time of the next purchase transaction so that the customer will continue to make purchases through e-commerce that already meets their needs and makes the customer feel satisfied.

The effect of e-satisfaction on e-loyalty was also shown through research conducted by Sardinha (2015). When ecommerce is able to meet the expectations of customers through the goods and services displayed in e-commerce, then the customer will feel satisfied and have a tendency to make repeat purchases and are loyal to the e-commmerce. The results of the Sardinha study are also supported by Tang and Huang's (2015) research which found a positive influence on e-commerce customer satisfaction on e-loyalty levels.

Customers who are satisfied with the services provided by an e-commerce will have a tendency to return to using ecommerce again. The level of customer satisfaction will affect the level of customers to re-use the same e-commerce to make purchases of the same or different products. Based on the description above, the hypothesis is proposed as follows: H6: there is an influence of e-customer satisfaction on e-loyalty, on figure 1.

\section{G. Effect of e-customer satisfaction on e-WOM}

E-word of mouth (e-WOM) is a positive or negative statement made by a customer, be it a potential customer, actual or existing customer about a product or company to many people or institutions through the internet [11]. Stauss states e-WOM as customer communication via the Internet that appears when customers provide reports or interact about consumption that has been done[11]. Davis and Khazanchi (2008) define online word of mouth as the ability of individuals to exchange opinions and experiences through online media.

Duarte et.al (2018) states that customer satisfaction has a significant positive effect on e-WOM [2]. This was stated in a study of 250 youth in Portugal who used e-commerce. Duarte et.al's research results show that when customers get satisfaction in using e-commerce, then customers will recommend e-commerce to those around them and tell positive experiences through social media. Narayandas (in Duarte et.al, 2018) said that customers who have or get a 
The $1^{\text {st }}$ International Conference on Business and Engineering Management (IConBEM 2020)

February $1^{\text {st }} 2020$, Institut Teknologi Sepuluh Nopember, Surabaya, Indonesia

satisfying experience from a retail will tend to provide positive word of mouth. Another study conducted by Akyuz (2013) identified several factors that could influence eWOM. These factors are customer susceptibility to interpersonal influence, experience of online usage and perceived credibility. These three factors have a positive influence on e-WOM.

E-Word of mouth (e-WOM) is a positive or negative statement made by a customer regarding the customer's experience or opinion of a brand or store and communicated to other parties through the Internet media. Duarte et.al (2018) in his research showed the influence of customer satisfaction on positive e-WOM from customers of an ecommerce [2]. Customers who are satisfied in using ecommerce, then these customers have a tendency to recommend e-commerce to those around them and tell positive experiences through social media. Narayandas (in Duarte et.al, 2018) also explained that customers who have or get a satisfying experience from a retail will tend to provide positive word of mouth to customers or other potential customers. Customers who get positive satisfaction from the services provided by an e-commerce will have a tendency to recommend e-commerce to others. The recommendations given can be through electronic platforms, one of which is social media. Based on the description above, the hypothesis is proposed as follows: H7: there is an influence of e-customer satisfaction on e-WOM, on figure 1.

\section{$H$. The effect of e-customer satisfaction on behavioral intentions}

Fishbein and Ajzen (in Davis, 1980) define behavioral intentions as the possibility of individuals to come up with certain behaviors that are subjective. Zeithaml et.al (1996) describes behavioral intentions as indicators that can be used to see whether customers will continue to use products and services from a company or will leave to move to products or services from other companies. There are 5 dimensions in behavioral intentions, namely loyalty to company (loyalty), propensity to switch (switch), willingness to pay more, external response to problem (external response) and internal response to problem (internal response). Zeithaml et.al (1996) said that behavioral intentions can also be measured as repurchase intentions, word of mouth, loyalty, complaining behavior, and price sensitivity.

Kuruuzum and Koksal (2010) in their research found an influence of service quality on the formation of positive behavioral intentions. The effect of service quality is also shown in research conducted by Zeithaml et al (1996). The study divides the two types of services provided, namely superior and inferior. Services that have superior quality will bring up favorable behavioral intentions for customers who receive services. Conversely, if the services provided have inferior quality, then customers will bring up unfavorable behavioral intentions towards the company. Other research conducted by Duarte et.al (2018) shows the influence of customer satisfaction on behavioral intentions.

Behavioral intentions are behavioral intentions shown by individuals related to the results of evaluations of products received from a company that will lead to the decision to survive or switch to products from other companies. Research conducted by Duarte et.al (2018) explains the positive influence of e-customer satisfaction on behavioral intentions. The results of the study indicate that when customers are satisfied shopping at online stores or retails, these customers will show positive behavior. This positive behavior is included in the form of favorable behavioral intentions explained by Zeithaml et.al (2016). The more satisfied the customer is, the customer has a tendency to go back to shopping using e-commerce, recommend to others, and make purchases in greater quantities and prices. Based on the description above, the hypothesis is proposed as follows: H8: there is an influence of e-customer satisfaction on behavioral intentions, on figure1.

\section{METHOD}

The target population in this study are all people who have used e-commerce to shop (Shopee, Tokopedia, Lazada, Bukalapak, Blibli.com) with the following characteristics; (1)Have made online purchases at least 5 times in the past one year; (2)Minimum educated high school / vocational school / equivalent assuming being able to understand and answer the statements in the questionnaire objectively; (3)Minimum age 15 years and over.

The sampling technique in this study is non-probability sampling, which is a sampling technique that makes each member of the population not have the same opportunity or opportunity to be selected as a sample. According to Loehlin (1998) the minimum number of samples needed for all types of SEM (Structural Equation Model) is 200. This aims to minimize the occurrence of bias in SEM analysis. Besides sampling also uses purposive sampling techniques, namely the selection of samples based on predetermined criteria. The use of sampling technique is because not all members of the population meet the criteria determined at the beginning of the study.

The data processing method in this study uses a general approach to data analysis in the Structural Equation Model (SEM) structural equation model:

\section{A. Validity Test}

The validity test used is the construct validity test. The first method to test the validity of using SPSS for windows by testing the items on the questionnaire with the Pearson Correlation coefficient of each statement with the total score obtained. If the results of the Pearson correlation between each statement with a total score produce a significance value of less than $0.05(\alpha=5 \%)$, then the statement item is valid. Validity test is done by using factor analysis. CFA (Confirmatory Factor Analysis) is used to test the validity of the items in the study by looking at standardize loading where the conditions must be above 0.5. In addition, the high average variance extracted (AVE) value indicates that the indicator has represented a well-developed latent construct. The average extracted variance value received was $\geq 0.50$ [12]. 
The $1^{\text {st }}$ International Conference on Business and Engineering Management (IConBEM 2020)

February $1^{\text {st }} 2020$, Institut Teknologi Sepuluh Nopember, Surabaya, Indonesia

\section{B. Reliability Test}

The approach used to measure reliability is carried out 2 times in different ways. The first way to test the reliability of approximately the first 30 questionnaires is to look at the results of the Cronbach's alpha coefficients of each construct. Declared reliable if Cronbach's alpha has a value above 0.7. Testing is done through SPSS for windows software. The second way to test reliability is by calculating CR (Composite reliability). The accepted composite reliability (CR) value is $\geq 0.70$ [12].

This research will use the PLS-SEM method. Partial Least Square according to Hair et al, (2014) is a powerful analysis method because it is not based on many assumptions. Assumptions on PLS are only related to structural equation modeling, and are not related to hypothesis testing, namely the relationship between latent variables in the inner model is linear and additive and the structural model is recursive. In general, the normal sample size in SEM analysis is greater than 100 [13]. Whereas the normal size in PLS is ten times the number of formative indicators (ignoring reflexive indicators) or ten times the number of structural paths in the innder model [13]. PLS has two indicator models in its description, namely the reflexive indicator model and the formative indicator model. The path analysis model of all latent variables in PLS consists of the following three sets of relationships: 1 . Outer model. The outer model defines how each indicator block relates to its latent variable. There are several factors that will be the focus for the outer model, including; (1)Convergent Validity. Convergent validity is the value of the loading factor on latent variables with the indicators. The minimum expected value in outer loading is $\geq 0.7$; (2)Composite Reliability. Data that has composite reliability $\geq 0.6$ has high reliability; (3)Average Variance Extracted (AVE) measures the validity of the model in a convergent and divergent expected AVE value $\geq 0.5$; (4)Multicolliniearity. Multicolliniearity test is conducted to find out the relationship between indicators and find out whether formative indicators experience multicolliniearity by knowing the value of VIF. Expected VIF value is $<10$.

2. Inner model. Inner model is used to see how strong the relationship between latent variables and can answer the hypothesis of the study. Here are a few factors that will focus on the inner model; (1)R square in endogenous constructs. $\mathrm{R}$ square value is the coefficient of determination in endogenous constructs to see how much endogenous variables can be explained by exogenous variables; (2)Hypothesis testing is done by looking at the $\mathrm{P}$ values that will determine the presence or absence of influence between variables. Hypothesis testing will be performed with a bootstrapping procedure.

\section{RESULT AND DISCUSSION}

Convergent validity testing uses outer loadings or loading factors. An indicator is said to meet the convergent validity test when it has an outer loadings value greater than 0.7 . Based on the above data presentation, it is known that each indicator dimension of the research variable shows a loading value $>0.7$ so that it can be said that all indicators are declared eligible or valid for research use and can be used for further analysis.

Composite reliability is a part that is used to see the level of reliability of each variable used in a study. A variable is said to be reliable when it has a composite reliability value $>0.6$ on figure 2.The table 1 shows that each variable used in this study has a high level of reliability because it has a composite reliability value above 0.6 so that each variable in this study can be said to be feasible to use. Average variance extracted (AVE) is used to see the validity of the variables used in research. The expected AVE value of each variable is $>0.5$. Based on the table 2 , it can be concluded that each variable in this study is valid and can be used for this study because it has a number $>0.5$. R-squares are used to measure how much endogenous variables are influenced by other variables. R2 values above 0.67 indicate the influence of exogenous variables on endogenous variables classified as high category. Meanwhile, if the result is $0.33-0.67$, it is categorized as medium, and if the result is below 0.33 , it is classified as low category. Based on the table 3 , it can be concluded that the influence of exogenous variables (independent variables) on endogenous variables (dependent variables) is classified as moderate because it has values in the range of 0.33 to 0.67 . Based on the data processing carried out produces data that can be used to answer the hypothesis in this study. Hypothesis testing in this study was conducted by looking at the P-values. The research hypothesis is declared acceptable when it has a P-value less than 0.05 .Based on the table 4 , it can be concluded that as many as 5 hypotheses were accepted in this study and there were 3 hypotheses that were rejected, namely hypothesis 2 , hypothesis 4 , and hypothesis 5 with significance at the 0.05 level.

Online convenience has a significant positive effect on ecustomer satisfaction. This is in line with previous studies conducted by Duarte et al. (2018) which explains the influence between these two variables. The research explains that customers are more focused on experiences that make them comfortable when shopping online through e-commerce and can save more time and effort to shop for a product [2].

Based on responses from respondents regarding online convenience variables indicate that the majority of respondents feel comfortable using e-commerce that has several payment methods. In addition, respondents will feel comfortable when e-commerce sites can be used wherever they are and easy to access the site. Some of the convenience felt by customers is what can affect the satisfaction felt by customers when shopping online through e-commerce [2].

Another thing that is important in online convenience is the suitability of the product and order status that can be tracked by customers through the application or e-commerce site directly. Customers will feel comfortable in shopping when getting products according to what is offered in the display of e-commerce sites. In addition, customers also need to know the existence of the product when in the shipping process. These factors are important to determine 
The $1^{\text {st }}$ International Conference on Business and Engineering Management (IConBEM 2020)

February $1^{\text {st }} 2020$, Institut Teknologi Sepuluh Nopember, Surabaya, Indonesia

customer convenience when conducting shopping transactions in an e-commerce [2]. When customers feel comfortable with the shopping process through e-commerce sites, customers will also easily feel satisfied with the services obtained during the purchase process on the ecommerce site. The rapid development of information technology makes customers from various places and at different times can search for the desired product. This makes the company try to be able to meet customer needs quickly by providing products on e-commerce sites [2]. Many companies are trying to provide high comfort in shopping online through existing e-commerce sites and make this a strategy to encourage customers to be satisfied and willing to make repeat purchases. This is what causes online convenience to be important in e-commerce sites to increase customer satisfaction in shopping online.

Data processing conducted in this study is related to the influence of website design on e-customer satisfaction rejecting the proposed hypothesis. This result also supports the research conducted by Ludin and Cheng (2014) which says that there is no influence of the website design variable on e-customer satisfaction. Luding and Cheng's research said that customers who use e-commerce sites do not have enough experience in conducting online transactions so they do not have a comparison of the quality of e-commerce site designs used with other e-commerce sites [6].

Other research conducted by Ranjbarian et al (2012) and Noronha and Rao (2017) shows that there is no influence between website design and e-customer satisfaction. This is in line with the findings in this study which explains that the website design of an e-commerce site has no effect on ecustomer satisfaction when shopping online. Both studies explain that website design is not an important factor in determining customer satisfaction when shopping online. Customers who make online transactions via e-commerce feel the design of the site or application that is displayed is not the main factor that determines satisfaction when shopping. Respondents will feel satisfied with e-commerce when the products that come in accordance with the order, payment methods that have several kinds of choices, and get a security guarantee when providing personal data. Respondents in the two previous studies illustrate other factors that are more influential on the level of e-customer satisfaction, namely security and convenience.

The results of data processing in this study indicate that there is an influence between security and e-customer satisfaction. The results of this study contradict the results of research conducted by Ludin and Cheng (2014). Research conducted by Ludin and Cheng (2014) explains that security does not have a significant effect on e-customer satisfaction. This is because security is more likely to influence and contribute to the variable of trust compared to customer satisfaction. The trust variable also cannot be used to be an indicator that customers are satisfied with the services provided [6].

Based on research conducted by Ranjbarian et al (2012) shows that security has a significant effect on e-customer satisfaction. This supports the results of this study which show the influence of security variables on e-customer satisfaction significantly. Research conducted by Harwani and Safitri (2017) also shows the effect of security on ecustomer satisfaction. When the security expected by customers in the online shopping process can be met by ecommerce parties, the customer will be satisfied with the services provided by e-commerce. Security that can be felt by the customer from the beginning the customer chooses the payment method, provides privacy data, until the product ordered by the customer is received in good condition and in accordance with the order.

Based on data processing carried out in this study shows that the e-service quality variable does not affect the ecustomer satisfaction variable. The results of this study contradict previous research conducted by Ludin and Cheng (2014) which explains the influence of e-service quality on e-customer satisfaction [6]. Based on these results it can also be said that when e-commerce seeks to provide e-service quality through sites or applications, it is not certain that it can provide satisfaction to customers when shopping online.

The results of this study indicate that respondents who participated in this study would not necessarily be satisfied even if they get good quality service from e-commerparties. This is in line with research conducted by Choi et al (2014), Yuktanandana and Prasertsakul (2015), and Noronha and Rao (2017) who explained that there is no influence of eservice quality variables on e-customer satisfaction variables. Even good service quality does not necessarily make customer satisfaction achieved. Choi et al (2014) said that the development of information technology infrastructure that is so rapidly developing in terms of speed, function, and service makes e-service quality no longer an important thing for customers when shopping online. This is what causes e-service quality is no longer a factor that determines the level of e-customer satisfaction in shopping online through e-commerce.

Data processing conducted in this study showed that information quality variables did not have a significant effect on e-customer satisfaction. This study contradicts previous research conducted by Ludin and Cheng (2014) [6]. The research explains that information quality is an important variable that influences the level of customer satisfaction in shopping in e-commerce.

The results of this study indicate that respondents involved in this study will not necessarily feel satisfied shopping at an e-commerce when the e-commerce is able to provide good quality information. The results of this study are in line with the research conducted by Deyalage and Kulathunga (2019) which states that information quality does not affect the level of customer e-customer satisfaction when shopping in e-commerce. The level of quality of product information provided by e-commerce will not always affect the satisfaction felt by customers when shopping through e-commerce. Information provided by one e-commerce with other e-commerce has in common, so it cannot be used as a comparison factor to increase customer shopping satisfaction [14].

Based on the results of data processing that has been done shows that the e-customer satisfaction variable has a significant positive effect on e-word of mouth. Customers 
The $1^{\text {st }}$ International Conference on Business and Engineering Management (IConBEM 2020)

February $1^{\text {st }} 2020$, Institut Teknologi Sepuluh Nopember, Surabaya, Indonesia

who are satisfied when shopping at an e-commerce will tend to provide positive feedback on the products sold in the ecommerce. Positive feedback given by customers can be a direct greeting to others, through social media, or provide online reviews on e-commerce sites that have been used. The results of this study support previous research conducted by Duarte et al (2018) which explains thsignificant influence of e-customer satisfaction on e-word of mouth.

Duarte et al (2018) explain that customers who get satisfying experiences when shopping at e-commerce will tend to talk about positive things about e-commerce used. Satisfied customers will have a tendency to talk about positive things related to the shopping experience on ecommerce sites to others. Feelings of pleasure and satisfaction will be shown by customers both directly to the people around, and through reviews on social media or ecommerce sites that are used [2].

Data processing conducted in this study shows that ecustomer satisfaction has a significant positive effect on behavioral intentions. This means that customers who are satisfied with e-commerce services will have a tendency to go back shopping through e-commerce and provide recommendations to others. The results of this study support previous research conducted by Duarte et al (2018) which shows the positive influence of e-customer satisfaction on behavioral intentions.

Customers who are satisfied with the services provided by e-commerce will tend to make repetitive transaction processes using e-commerce and recommend e-commerce products and sites to those around them [2]. When the customer has finished making an online shopping transaction and e-commerce is able to meet what the customer needs, the customer will feel satisfied. Satisfied customers will tend to have the intention to go back to shopping at e-commerce, recommend it to others, and even tend to have the courage to pay more to get products that suit your needs. Customers who get satisfaction when shopping through an e-commerce will also have a low tendency to move to other e-commerce sites.

Based on the data processing that has been done, shows that there is an influence of e-customer satisfaction on eloyalty. This means that the higher the level of satisfaction felt by customers when shopping at e-commerce, the higher the level of customer loyalty to the e-commerce site. The results of this study support previous research conducted by Ludin and Cheng (2014) which explains that there is an influence of e-customer satisfaction on e-loyalty.

Ludin and Cheng (2014) say that customers who are satisfied with the services obtained during shopping at ecommerce, will have a tendency to make repeat purchases and be loyal to use the e-commerce site. This is also in line with research conducted by Lin in 2013 [6]. Lin (2013) said that customers who have met their expectations of a service will feel satisfied, when customers feel satisfied it will tend to be loyal to e-commerce that has been used and will return to use e-commerce when you want to shop again[6].

This study has several limitations that will be elaborated along with recommendations for further research. This study most of the respondents came from the city of Surabaya. Further research can be done in several other big cities with a balanced proportion of respondents so that they can see the characteristics of e-commerce users from various cities in

Indonesia. This research is aimed at all e-commerce users in Indonesia (Tokopedia, Shopee, Bukalapak, Blibli, JDid, etc.). Future research can use one e-commerce company so that it can be more focused and clear in testing the variables used. This study combines the favorable and unfavorable dimensions of the behavioral intentions variable in conducting the analysis. Subsequent research could separate the two dimensions to see how many respondents responded to the two dimensions. There are 3 variables that are not proven to affect the e-customer satisfaction variable, namely website design, e-service quality, and information quality. Future studies can continue to look at the effect of these 3 variables on e-customer satisfaction, or use other variables to find out the factors that can influence e-customer satisfaction of customers who use e-commerce.

\section{REFERENCES}

[1] N. S. Subawa and N. W. Widhiasthini, "Transformasi perilaku konsumen era revolusi industri 4.0," Conf. Manag. Behav. Stud., 2018.

[2] P. Duarte, S. Costa e Silva, and M. B. Ferreira, "How convenient is it? delivering online shopping convenience to enhance customer satisfaction and encourage e-wom,” J. Retail. Consum. Serv., vol. 44, no. May, pp. 161-169, 2018, doi: 10.1016/j.jretconser.2018.06.007.

[3] M. Jun, Z. Yang, and D. S. Kim, “Customers' perceptions of online retailing service quality andttheir satisfaction,” Int. J. Qual. Reliab. Manag., vol. 21, no. 8, pp. 817-840, 2004, doi: 10.1108/02656710410551728.

[4] D. M. Szymanski and R. T. Hise, "E-satisfaction: an initial examination,” J. Retail., vol. 3, pp. 309-322, 2000.

[5] B. Ganguly, S. B. Dash, D. Cyr, and M. Head, "The effects of website design on purchase intention in online shopping: the mediating role of trust and the moderating role of culture," Int. J. Electron. Bus., vol. 8, no. 4/5, p. 302, 2010, doi: 10.1504/ijeb.2010.035289.

[6] M. Dynamics, K. E. Volume, T. Books, I. H. Bt, H. Ludin, and B. L. Cheng, "Factors influencing factors influencing customer satisfaction and e-loyalty: online shopping environment among the young adults," Manag. Dyn. Knowl. Econ., vol. 2, no. 3, pp. 462-471, 2014.

[7] X. Guo, K. C. Ling, and M. Liu, "Evaluating factors influencing consumer satisfaction towards online shopping in china," Asian Soc. Sci., vol. 8, no. 13, pp. 40-50, 2012, doi: 10.5539/ass.v8n13p40.

[8] V. A. Zeithaml, L. L. Berry, and A. Parasuraman, "The behavioral consequences of service quality,” J. Mark., vol. 60, no. 2, pp. 31-46, Apr. 1996, doi: 10.2307/1251929.

[9] H. Miller, “The multiple dimensions of information quality,” Inf. Syst. Manag., vol. 13, no. 2, pp. 79-82, 1996.

[10] N. F. Dewi, S. M. Ferdous Azam, and S. K. M. Yusoff, "Factors influencing the information quality of local government financial statement and financial accountability,” Manag. Sci. Lett., vol. 9, no. 9, pp. 1373-1384, 2019, doi: 10.5267/j.msl.2019.5.013.

[11] T. Hennig-Thurau, K. P. Gwinner, G. Walsh, and D. D. Gremler, "Electronic word-of-mouth via consumer-opinion platforms: what motivates consumers to articulate themselves on the internet?," $J$. Interact. Mark., vol. 18, no. 1, pp. 38-52, 2004, doi: 10.1002/dir.10073.

[12] Hair and J. H, Multivariate data analysis. New York: Prentice Hall, 2010.

[13] J. F. Hair, M. Sarstedt, L. Hopkins, and V. G. Kuppelwieser, "Partial least squares structural equation modeling (PLS-SEM): An emerging tool in business research,” Eur. Bus. Rev., vol. 26, no. 2, pp. 106-121, 2014, doi: 10.1108/EBR-10-2013-0128.

[14] P. A. Deyalage and D. Kulathunga, "Factors affecting online customer satisfaction: the sri lankan perspective,” Int. J. Bus. Manag., vol. 14, no. 2, p. 99, 2019, doi: 10.5539/ijbm.v14n2p99. 